7. Reprod. Fert. (1966) 12, 65-73

REVIEW

\title{
URINARY OESTROGENS IN THE MALE
}

\author{
WEIERT VELLE
}

\author{
Department of Physiology, The Veterinary College of Norway, Oslo, Norway
}

Summary. Oestrogenic activity in urine from males was detected as early as 1927. A few years later mass excretion of oestrogens was detected in the stallion and other equines, and in the boar.

The following naturally occurring oestrogens have been chemically identified in urine from males: oestrone (stallion, bull, boar, man, rat), oestradiol-17 $\beta$ (stallion, boar, man, rat), oestradiol-17 $\alpha$ (stallion, rat), oestriol (man).

The levels of oestrogens in male urine is subject to very marked species differences, the stallion showing extremely high levels, followed by other equines and by the domestic boar. During recent years a large number of wild animals has been screened for oestrogens in urine. Generally the values are very low, a few $\mu \mathrm{g} / 100 \mathrm{ml}$ of urine, while for stallion's urine the values recorded are in the $\mathrm{mg}$ range.

The testicular origin of the major part of urinary oestrogens was early anticipated and has been confirmed by recent biochemical investigations. A minor part is probably of adrenal origin.

The biological significance of oestrogenic hormones in the male is obscure. Mass secretion of the hormones in males of some species still represents an enigma.

The first unequivocal demonstration of the presence of a specific oestrogenic hormone in the mammalian ovary was made about 40 years ago (Allen \& Doisy, 1923, 1924). The designation of the substance as the female sex hormone (Frank, 1929) seemed at first to be appropriate, especially since its presence had by then been demonstrated in female blood (Loewe, 1925) and in human pregnancy urine (Aschheim \& Zondek, 1927).

These original observations pertaining to the female were, however, soon followed by reports of some oestrogen activity also in testes, and in urine from men, indicating that oestrogenic hormones were not entirely sex specific. Then followed the first reports on very high levels of oestrogenic activity in stallion's urine which paradoxically appeared to be one of the richest sources ever found for 'female sex hormones'.

Those who have seen a fiery stallion will hardly refute its masculinity. Nevertheless, its daily oestrogen output exceeds that of the non-pregnant female animal by a factor of 100 to 200 .

Ever since this discovery, the question of how a male may retain its masculinity in spite of such an enormous oestrogen secretion has remained one of the 
enigmas of biology. Recent research has added little or nothing to our understanding of the problem.

The earliest qualitative and quantitative measurements of oestrogens were done by the biological method developed by Allen \& Doisy. In the 1930s, oestrogens from various sources, including urine from males of some species, were identified chemically. During the last decade great progress has been made in development of quantitative chemical methods, and much additional information on urinary oestrogens in the male has been accumulated, covering a wide variety of animal species.

The present paper is an attempt to review the work done so far in this field.

\section{Early observations on oestrogenic activity in the urine of males}

The first reports on oestrogenic activity in urine from males appeared in the late 1920s (Laqueur, Dingemanse, Hart \& de Jongh, 1927; Loewe, Voss, Lunge \& Wöhner, 1928; Fee, Marrian \& Parkes, 1929; Glimm \& Wadehn, 1930).

Laqueur et al. (1927) reported values of up to $50 \mathrm{~m} . \mathrm{u} . / \mathrm{l}$ of human male urine and concluded that the hormone was a normal urine constituent in healthy, sexually mature men. Somewhat higher values were found by Glimm \& Wadehn (1930) who gave an average value of 500 m.u./l for men between 25 and 35 years of age. Numerous later reports have substantiated the first observations (for references, see Diczfalusy \& Lauritzen, 1961).

The presence of high levels of oestrogenic activity in stallion's urine seems to have been reported first by Küst (1932) who stated that all samples taken from sexually mature animals without exception provoked a strongly positive reaction in the test animals. No quantitative data were, however, given.

Zondek (1933) presented the first quantitative estimates of oestrogens in stallion's urine and reported an average value of 42,000 m.u. $/ 1$. On the basis of a diuresis of $10 \mathrm{l}$, he calculated the daily oestrogen output of the stallion to be of the order of $40 \mathrm{mg}$ oestrone equivalents In this paper and in one that was published the following year (Zondek, 1934a) he states that Häussler made the discovery of the high oestrogen content of stallion's urine.

Zondek (1934a) found mass excretion of oestrogens in male animals to be a peculiarity of the equines. Thus he reported high values also for the male zebra, the Grevy-zebra, the ass and the Kiang, but low values for the bull and the male dromedary.

In the meantime high levels of oestrogenic activity had, however, also been observed in the urine of the domestic boar (Hauer, 1933; Küst, 1934).

Few other species seem to have been investigated until quite recently.

\section{Chemical identification of oestrogens in urine from males}

The first steroid hormone ever isolated was oestrone which was obtained in crystalline form from human pregnancy urine (Butenandt, 1929; Doisy, Veler \& Thayer, 1929).

Six years later oestrone was crystallized from stallion's urine by Häussler (1934) and by Deulofeu \& Ferrari (1934). A decade later Levin (1945) observed that a major proportion of the oestrogenic activity of stallion's urine was present 
in the weakly phenolic, non-ketonic fraction of the extract. From this fraction he isolated oestradiol-17 $\beta$ (at that time designated $\alpha$-oestradiol) in good yield (Levin, 1945, 1949).

Oestrone and oestradiol-17 $\beta$ were the only two oestrogens known to be present in stallion's urine until recently when Pigon, Lunaas \& Velle (1961) in addition also identified oestradiol-17 $\alpha$. These authors concluded from their investigations that a marked sex difference seemed to exist in the horse, in so far as the ring B-unsaturated compounds characteristic for the urine of the pregnant mare seemed to be absent from the urine of the male. Ring B-unsaturated oestrogens have, however, now also been found in trace amounts in stallion's urine (Savard, personal communication, 1962).

From the urine of the human male Dingemanse, Laqueur \& Mühlbock (1938) isolated oestrone in crystalline form. To obtain $6 \mathrm{mg}$ of the pure substance, 16,000 1 of urine was extracted. More recently the presence of oestrone as well as oestradiol-17 $\beta$ and oestriol has been repeatedly demonstrated in the urine of men by highly specific chemical methods (see Diczfalusy \& Lauritzen, 1961).

From bulls' and steers' urine Marker (1939a, b) isolated oestrone in low yield. Oestrone and oestradiol-17 $\alpha$ were identified in urine from newborn calves of both sexes by Velle (1958d).

The identity of the oestrogens present in the urine of the domestic boar was not established until 1958 when oestrone and oestradiol-17 $\beta$ were identified by various criteria, including infrared spectro-photometry (Velle, 1958a, c).

Naturally occurring oestrogens of male dog's urine have not been identified, but recent studies show that oestrone as well as oestradiol-17 $\alpha$ are urinary metabolites after injected oestradiol-17 $\beta$ (Siegel, Dorfmann, Brodey \& Friedman, 1962).

In urine from male rats oestrone, as well as oestradiol-17 $\beta$ and oestradiol-17 1 , were identified by paper chromatographic methods by Ketz (1961).

Recent research indicates that the domestic hen shows a metabolic pattern for oestrogens similar to that of man. In the droppings of the rooster Hurst, Kuskis \& Blendell (1957) identified oestrone, oestradiol-17 $\beta$ and oestriol. At least the hormones may in part be supposed to have been excreted via the kidney, since a recent investigation based on separate collection of urine shows this to be an important excretory pathway in the laying hen (Hertelendy, Taylor, Mathur \& Common, 1965).

The form in which the oestrogens occur in male urine has not yet been thoroughly investigated. As early as $1930 \mathrm{Glimm} \&$ Wadehn found that the oestrogens present in men's urine were only partly extractable by ethyl ether, and that boiling of the urine with alkali, with subsequent acidification gave higher yields. Zondek (1934a) stated that of the oestrogenic activity present in stallion's urine, only 5 to $25 \%$ was taken up by ether from untreated urine, while most of the activity present could be obtained if ether extraction was preceded by acidification and boiling. As is now known, this is due to the fact that oestrogens generally are present in conjugate forms in urine. Also Pigon et al. (1961) found only trace amounts of free oestrogens to be present in ether extracts of freshly collected, unhydrolysed samples of urine from stallions. The 
same was found to be the case for the urine of boars (Velle, 1958b), and of newborn male calves (Velle, 1958d).

The only conjugate so far isolated from male urine is oestrone sulphate which was crystallized from stallion's urine by Jensen, Larivière \& Elie (1945).

\section{Levels of urinary oestrogens in males of various species}

Since the collection of 24-hr specimens of urine is usually not practicable for domestic and wild animals, the basis for comparison between the species has to be the oestrogen concentrations in the urine.

The early quantitative assay of oestrogens were all made by biological methods using more or less crude extracts for the injections. One of the major limitations of these methods is due to the great difference in biological activity between the various oestrogens. Although bio-assays may give reliable results as regards oestrogenic activity, information on the actual concentrations of the different steroids must be sought by other methods.

The data included in Table 1 are all based on chemical determinations, usually by combination of chromatographic methods and spectophotometry of fluorimetry. Most of the data on wild animals are recalculated from a recent publication of Heidermanns \& Kirchner-Kühn (1963), who made an extensive survey of urinary oestrogen excretion in various species using chemical methods.

In spite of the great extension of the number of species investigated since 1934, the equines still seem to share the monopoly of high oestrogen secretion only with the boar. An exception is the newborn male bovine which excretes large amounts of oestradiol-17 $\alpha$ and some oestrone during the first days of life (Velle, 1958d).

\section{Origin of the urinary oestrogens in the male}

The question of the origin of the urinary oestrogens of the male was raised soon after its original discovery. Laqueur (1926) and Dohrn (1927) had detected oestrogen activity in the testes. Fee, Marrian \& Parkes (1929) as well as Glimm \& Wadehn (1930) discussed the possibility of its origin being ingested food, but no conclusion was reached. Fee et al. (1929) attempted to measure oestrogens in the urine of rabbits before and after castration, in order to find evidence for testicular origin of the hormone, but the attempts had to be abandoned since the extracts were found to be highly toxic. Zondek (1934a) found, however, that the urine of geldings contained only about $0.3 \%$ of the amount present in intact stallions. He also found that the testes of stallions showed extremely high levels of oestrogenic activity $(66,000 \mathrm{~m} . \mathrm{u} . / \mathrm{kg})$ as opposed to the testes of the bull (less than $50 \mathrm{~m} . \mathrm{u} . / \mathrm{kg}$ ). These observations seemed to establish the testes as at least a major source of urinary oestrogens.

As regards the biosynthesis of the oestrogens in the male, it is remarkable that Zondek already in 1934, before anything was known about the biochemical reactions involved, stated that the female hormone present in the male organism quite possibly is a conversion product of the male hormone (Zondek, 1934b). This has indeed turned out to be the case.

Oestrone and oestradiol-17 $\beta$ were isolated in crystalline form from horse testes by Beall (1940). The same two hormones were identified in the testes 


\section{TABLE 1}

CONGENTRATION OF OESTROGENS IN URINE OF MALES

\begin{tabular}{|c|c|c|c|c|}
\hline \multirow{2}{*}{$\begin{array}{l}\text { Order or } \\
\text { family }\end{array}$} & \multirow{2}{*}{ Species } & \multirow{2}{*}{$\begin{array}{c}\text { No. of } \\
\text { observations }\end{array}$} & \multicolumn{2}{|c|}{$\mu g$ oestrogen $/ 100 \mathrm{ml}$ of urine } \\
\hline & & & Oestrone & Oestradiol-17 $\beta$ \\
\hline Endentata & $\begin{array}{l}\text { Earth-pig } \\
\text { Sloth } \\
\text { Ant-eater }\end{array}$ & $\begin{array}{l}1 \\
2 \\
1\end{array}$ & $\begin{array}{c}0.3 \\
0 \text { to } 0 \cdot 4 \\
3 \cdot 2\end{array}$ & \\
\hline Marsupialia & $\begin{array}{l}\text { Oppossum } \\
\text { Brush-tailed oppossum } \\
\text { Kangaroo }\end{array}$ & $\begin{array}{l}1 \\
4 \\
1\end{array}$ & $\begin{array}{c}2 \cdot 4 \\
0 \text { to } 0.9 \\
12.9\end{array}$ & \\
\hline Insectivora & Hedgehog & 1 & $1 \cdot 4$ & \\
\hline Rodentia & $\begin{array}{l}\text { Rat } \\
\text { Rat } \\
\text { Rabbit } \\
\text { Agouti }\end{array}$ & $\begin{array}{l}1 \\
2\end{array}$ & $\begin{array}{c}0 \\
5 \text { to } 14^{a} \\
0.8 \\
0\end{array}$ & \\
\hline Canidae & $\begin{array}{l}\text { Wolf } \\
\text { Hyena } \\
\text { Dog } \\
\text { Dog }\end{array}$ & $\begin{array}{l}1 \\
2 \\
9 \\
3\end{array}$ & $\begin{array}{c}0.6 \\
0 \text { to } 0.7 \\
0 \text { to } 1.6 \\
0\end{array}$ & \\
\hline Mustelidae & $\begin{array}{l}\text { Skunk } \\
\text { Wolverine }\end{array}$ & $\begin{array}{l}1 \\
1\end{array}$ & $\begin{array}{c}2 \cdot 0 \\
0\end{array}$ & \\
\hline Viveridae & Genet & 1 & 0 & \\
\hline Procyonidae & Racoon & 7 & 0 to 1.3 & \\
\hline Ursidae & $\begin{array}{l}\text { Kodiak bear } \\
\text { Brown bear } \\
\text { Polar bear }\end{array}$ & $\begin{array}{l}3 \\
2 \\
2\end{array}$ & $\begin{array}{l}0.1 \text { to } 0.8 \\
0.2 \text { to } 1.2 \\
0.7 \text { to } 1.8\end{array}$ & \\
\hline Hippopotamidae & Hippopotamus & $i$ & 1.5 & \\
\hline Suidae & $\begin{array}{l}\text { Domestic pig }{ }^{3} \\
\text { Domestic pig } \\
\text { Castrated pig } \\
\text { Warthog }\end{array}$ & $\begin{array}{r}10 \\
1 \\
1 \\
1\end{array}$ & $\begin{array}{c}192 \text { to } 451 \\
1100 \text { to } 5800^{a} \\
1 \cdot 2 \\
6 \cdot 2\end{array}$ & $\begin{array}{l}10 \text { to } 388 \\
110 \text { to } 1020^{\mathrm{a}}\end{array}$ \\
\hline Rhinocerotidae & Rhinoceros & 3 & 0 to $12 \cdot 4$ & \\
\hline Tapiridae & Tapir & 4 & 0 to 32 & \\
\hline Equidae & $\begin{array}{l}\text { Horse } \\
\text { Mature } \\
7 \text { to } 12 \text { months }^{5} \\
13 \text { to } 22 \text { months }^{5} \\
23 \text { to } 37 \text { months }^{5} \\
\text { Mature } \\
\text { Geldings } \\
\text { Pony } \\
\text { Ass } \\
\text { Grant zebra } \\
\text { Grevy zebra }\end{array}$ & $\begin{array}{r}11 \\
10 \\
14 \\
8 \\
10 \\
1 \\
2 \\
1 \\
3\end{array}$ & $\begin{array}{c}840 \\
0.1 \text { to } 9 \cdot 1 \\
2 \cdot 8 \text { to } 393 \\
222 \text { to } 2545 \\
1420 \text { to } 3202 \\
0.6 \text { to } 6,1 \\
117 \\
13 \cdot 0 \text { to } 204 \\
180 \\
0 \text { to } 9 \cdot 6\end{array}$ & $\begin{array}{c}0 \text { to } 5.7 \\
0.2 \text { to } 47 \\
28 \text { to } 234 \\
101 \text { to } 271 \\
0.9 \text { to } 6.1\end{array}$ \\
\hline Camelidae & $\begin{array}{l}\text { Camel } \\
\text { Guanaco }\end{array}$ & $\begin{array}{l}4 \\
1\end{array}$ & $\begin{array}{c}0.8 \text { to } 9.1 \\
2.6\end{array}$ & \\
\hline Cervidae & $\begin{array}{l}\text { Wapiti } \\
\text { Reindeer }\end{array}$ & $\begin{array}{l}1 \\
2\end{array}$ & $\begin{array}{c}14.4 \\
0.4 \text { to } 45\end{array}$ & \\
\hline Giraffidae & Okapi & 1 & 0 & \\
\hline Bovidae & $\begin{array}{l}\text { Bison } \\
\text { Antelope } \\
\text { Bull } \\
\text { Steer }\end{array}$ & $\begin{array}{l}1 \\
1 \\
1\end{array}$ & $\begin{array}{l}0 \cdot 8 \\
0 \cdot 8 \\
0 \cdot 1 \\
2 \cdot 4\end{array}$ & $0 \cdot 2$ to $0 \cdot 6^{b}$ \\
\hline Primates & $\begin{array}{l}\text { Chimpanzee } \\
\text { Gorilla } \\
\text { Orang Utan } \\
\text { Man }^{8}\end{array}$ & $\begin{array}{l}2 \\
2 \\
1\end{array}$ & $\begin{array}{c}0.3 \text { to } 5.1 \\
1.2 \text { to } 3.5 \\
11,4 \\
1 \text { to } 8^{\mathrm{a}} \\
\text { (and oestriol } 1 \text { to } 8^{\mathrm{a}} \text { ) }\end{array}$ & 0 to $3^{a}$ \\
\hline
\end{tabular}

a Values represent $24 \mathrm{hr}$ excretion. ${ }^{b}$ Probably oestradiol-17 $\alpha$.

${ }^{1}$ Ketz (1961). ${ }^{2}$ Kristoffersen \& Velle (1960). ${ }^{3}$ Velle (1958b). ${ }^{4}$ Raeside (1965). ${ }^{5}$ Pigoń et al. (1961). ${ }^{6}$ Velle (1957). ${ }^{7}$ Marker (1939a). ${ }^{8}$ Many authors (for references, see Diczfalusy \& Lauritzen, 1961).

The results have been obtained by chemical methods. Unless otherwise stated, the data have been calculated from Heidermanns \& Kirchner-Kuhn (1963) and are given as $\mu$ g oestrone equivalents/100 $\mathrm{ml}$ of urine. 
from boars (Velle, 1958c). Oestradiol-17 $\beta$ has been identified in the human testes (Goldzieher \& Roberts, 1952). Isolation of a substance from an organ is no proof of its origin in that organ. However, Paschkis \& Rakoff (1950) were able to show that the oestrogenic activity of testicular vein blood from stallions was about 20 times higher than that of peripheral blood.

Direct demonstration of the biosynthesis of oestrogens from testosterone in homogenates of stallion testes was made by Baggett, Engel, Balderas \& Lanman (1959). Furthermore, substantial amounts of oestrone and oestradiol-17 $\beta$ were synthesized from acetate by a perfused stallion testis following previous in-vivo gonadotrophin-priming of the animal (Nyman, Geiger \& Goldzieher, 1959).

In the domestic boar the values for urinary oestrogens fall markedly following castration (Velle, unpublished data). On the other hand, urinary oestrogen excretion can be markedly increased by gonadotrophin stimulation, in man (Diczfalusy, 1957; Hammerstein, 1960) and in the boar (Lunaas \& Velle, 1965; Raeside, 1965). Synthetic gestagens, presumably by inhibiting gonadotrophin secretion and/or release, are potent inhibitors of oestrogen excretion in the boar (Lunaas \& Velle, 1965; Raeside, 1965). It is of interest in this connection that the testes of the gestagen-dominated animal is still responsive to exogenous gonadotrophin stimulation, as shown by grossly increased urinary excretion of 17-ketosteroids as well as oestrogens (Garm, Lunaas \& Velle, unpublished data).

There thus seems to be no doubt that at least a substantial part of the urinary oestrogens of the male is of testicular origin. According to several earlier investigations the testes in men are generally supposed to account for about $80 \%$ of the urinary oestrogens, while about $20 \%$ is of adrenal origin (see Diczfalusy \& Lauritzen, 1961). For domestic or other animals information on this point is limited, but the few data available suggest that an even greater percentage is derived from the testes in the stallion and the boar. The isolation of oestrone from the urine of steers (Marker, 1939b), and the fact that the same hormone has also been isolated from bovine adrenals (Beall, 1939) points to the adrenal as an important source for urinary oestrogens in this species, especially since testis (Zondek, 1934a) and urine (Velle, 1957) of bulls possess very low oestrogenic activity.

The cellular origin of testicular oestrogens has been the subject of much debate. Both Sertoli cells and Leydig cells have been regarded as the cells of origin (for a discussion see, e.g. Maddock \& Nelson, 1952; Diczfalusy \& Lauritzen, 1961). The question does not seem to have been finally settled.

\section{Clinical significance of urinary oestrogen determinations in the male}

In some species the normal testis will respond to gonadotrophin stimulation with increased oestrogen secretion. In man this fact has been taken advantage of in the evaluation of testicular function. Several authors claim that quantitative determinations of urinary oestrogens in connection with gonadotrophin injections constitute a reliable test of testicular function in the diagnosis of male hypogonadism (Maddock \& Nelson, 1952; Leach, Maddock, Tokuyama, Paulsen \& Nelson, 1956; Hammerstein, 1960). 
Spontaneously increased urinary oestrogen excretion is usually due to hormone-producing tumours, which occurrence has been described especially in man and the dog.

So far as testicular tumours are concerned, Leydig-cell tumours and chorioepithelioma of the testis have been shown to be associated with increased urinary oestrogen excretion in men, and Sertoli-cell tumours causing feminization have been described in men and dogs.

In men, tumours of adrenal origin have also been found to be associated with feminization and increased urinary oestrogen excretion.

Urinary oestrogen determinations with or without gonadotrophin stimulation have been recommended as diagnostic aids in these diseases.

The literature concerning tumours and oestrogen excretion in the male is extensive, and interested readers are referred to the book by Diczfalusy \& Lauritzen (1961) and to other handbooks.

The possible relation between oestrogen excretion and testicular function in stallions was studied by Bielansky \& Ewy (1951) who found no significant correlation between urinary oestrogen concentrations and the volume of semen, its density or sperm motility. However, the decrease in hormone concentration with advancing age was associated with an increased number of spermatozoa showing 'secondary changes', i.e. changes arising after the admixture of the spermatozoa with the seminal plasma. The authors therefore suggest that the oestrogens may indirectly be responsible for these changes, by way of altering the composition of the seminal plasma.

In mature, normally fertile boars very marked variations in urinary oestrogen concentrations were observed for single animals as well as between animals (Velle, 1958b). The use of urinary oestrogen determinations for diagnostic purposes therefore seems to be of little promise in this species, and has so far not gained any clinical significance in domestic animals.

\section{The biological function of oestrogens in the male}

As is evident from Table 1, urinary oestrogen excretion is low in males of most species, and there seems to be no evidence for any biological significance of the small amounts produced. On this basis the question of the biological function of oestrogens in those few species in which secretion rate is high becomes even more difficult. Zondek (1934b) expressed the view that "in the male organism the female hormone constitutes a degradation product of the male hormone which is then rapidly excreted". So far as biosynthesis is concerned, this view has been shown to be correct. However, there can be no doubt that the 'degradation products' possess high biological activity when given to test animals, whether extracted from blood or urine. The fact that neither the stallion nor the boar shows any signs of feminization or hyperoestrogenism, requires an explanation. One possibility is that the circulating oestrogens exist in an inactive form, bound to proteins or other substances. This should be investigated. Another explanation might be unresponsiveness of male tissues to the action of oestrogens. However, at least in some species in which oestrogen secretion is normally low (man, dog), oestrogen treatment will give clear signs of feminization. In this connection it is especially noteworthy also that the castrate 
boar has been shown to respond to exogenous oestrogens with mammary development, and with regained ability to erection of the penis and arousal of sexual desire (Dinusson, Klosterman \& Buchanan, 1951). In these experiments the substance used was stilboestrol, which was implanted subcutaneously. This compound may, however, behave differently from the naturally occurring oestrogens in the male pig.

The possibility that the effects of oestrogens secreted in the male may be counteracted by the simultaneously produced androgens cannot be dismissed.

The only practicable way of testing the biological significance of oestrogens in the male would seem to be by blocking aromatization without interfering with androgen biosynthesis. Perhaps this possibility is not too remote.

\section{REFERENGES}

Allen, E. \& Doisy, E. A. (1923) An ovarian hormone. 7. Am. med. Ass. 81, 819.

Allen, E. \& Doisy, E. A. (1924) The extraction and some properties of an ovarian hormone. f. biol. Chem. 61, 711.

AschHerm, S. \& Zondek, B. (1927) Hypophysenvorderlappenhormon und Ovarialhormon im Harn von Schwangeren. Klin. Wschr. 6, 1322.

Baggett, B., Engel, L. L., Balderas, L. \& Lanman, G. (1959) Conversion of $\mathbf{C}^{14}$-testosterone to $\mathrm{C}^{14}$-estrogenic steroids by endocrine tissues. Endocrinology, 64, 600.

BEALL, D. (1939) Isolation of oestrone from the adrenal gland. Nature, Lond. 144, 76.

BEALL, D. (1940) The isolation of alpha-oestradiol and oestrone from horse testes. Biochem. 7. 34, 1293.

Bielansky, W. \& Ewy, Z. (1951) The effect of oestrogens on the reproductive functions of the stallion. Acta endocr., Copenh. 6, 272.

Butenandt, A. (1929) Untersuchungen über das weibliche Sexualhormon. Darstellung und Eigenschaften des Kristallisierten 'Progynons'. Dt. med. Wschr. 55, 2171.

Deulofeu, V. \& Ferrari, J. (1934) Krystallisiertes $\alpha$-Follikelhormon aus Hengstharn. Z. physiol. Chem. 226, 192.

Diczfalusy, E. (1957) Chemical determination of oestrogens in urine. Acta endocr., Copenh. 24, Suppl. 31,11 .

Diczfalusy, E. \& Lauritzen, C. (1961) Oestrogene beim Menschen. Springer, Berlin.

Dingemanse, E., LAqueUR, E. \& MüHLbock (1938) Chemical identification of oestrone in human male urine. Nature, Lond. 141, 927.

Dinusson, W. E., Klosterman, E. W. \& Buchanan, M. L. (1951) Stilbestrol, effect of subcutaneous implantation on growing-fattening swine. 7. Anim. Sci. 10, 885.

Dohrn, M. (1927) Ist der Allen-Doisy-Test spezifisch für das weibliche Sexualhormon? Klin. Wschr.6, 359.

Doisy, E. A., Veler, C. D. \& Thayer, S. A. (1929) Folliculin from urine of pregnant women. Am. $\mathcal{F}$. Physiol. 90, 329.

FEe, A. R., Marrian, G. F. \& Parkes, A. S. (1929) The significance of the occurrence of oestrin in male urine. 7. Physiol., Lond. 67, 377.

Frank, R. T. (1929) The female sex hormone. Thomas, Springfield.

Grimm, E. \& Wadehn, F. (1930) Über Sexualhormone, insbesondere das Feminin. Biochem. Z. 219, 155.

GoldzieHer, J. W. \& Roberts, I. S. (1952) Identification of estrogen in the human testis. 7 . clin. Endocr. Metab. 12, 143.

Hammerstein, J. (1960) Die Beeinfussung des Harnsteroidspektrums bei Gesunden im geschlechtsreifen alter durch menschliches choriongonadotropin. 6. Symp. der deutsche Gesellsch. f. Endokrinologie, 393. Springer, Berlin.

HAUER, J. (1933) Zur Trächtigkeitsdiagnose beim Schwein durch den Nachweis des Ovarialhormons im Harn. Wien tierärztl. Wschr. $20,699$.

HäussLER, E. P. (1934) Über das Vorkommen von $\alpha$-Follikelhormon (3-Oxy-17-keto-1,3,5-oestratrien) im Hengsturin. Helv. chim. Acta, 17, 531.

Heidermanns, C. \& Kirchner-Kühn, I. (1963) Die Ausschiedung von Wirkstoffen im Harn von Wild- und Nutztieren. III Die Ausscheidung von oestrogenen Substanzen, pp. 67. Westdeutscher Verlag, Koln und Opladen.

Hertelendy, F., Taylor, T. G., Mathur, R. S. \& Common, R. H. (1965) Isolation of estradiol-17 $\beta$ from hen's urine and its characterization as the crystalline 3-methylether. Can. F. Biochem. 43, 1379. 
Hurst, R. O., Kuskis, A. \& Blendelx, J. F. (1957) The separation of estrogens from avian droppings. Can. J. Biochem. Physiol. 35, 637.

Jensen, H., LARIVIÈRE, M. \& EliE, J. J. (1945) Isolation of oestrone sulfate from the urine of stallions. Revue can. Biol. 4, 535.

KETZ, H.-A. (1961) Die Ausscheidung von neutralen und phenolischen Steroiden bei der Ratte. Biochem. Z. 334, 73.

Kristoffersen, J. \& Velle, W. (1960) Urinary oestrogens of the dog. Nature, Lond. 185, 253.

Küst, D. (1932) Die Feststellung der Trächtigkeit der Stute durch Hormonnachweis im Blute. Berl. tierärztl. Wschr. 48, 817.

Küst, D. (1934) Über Sexualhormone bei den Haustieren. Klin. Wschr. 13, 1782.

LAQUEUR, E. (1926) Uber das weibliche Sexualhormon (Menformon) in besonderen seine Eichung. Verhandl. dtsch. pharmakol. Gesellsch. 6. Tagung. p. 82. Vogel, Leipzig. (Suppl. to Arch. exp. Path. Pharmak. $119,1927)$.

Laqueur, E., Dingemanse, E., Hart, P. G. \& de Jongh, S. E. (1927) Über das Vorkommen weiblichen Sexualhormons (Menformon) im Harn von Männern. Klin. Wschr. 6, 1859.

Leach, R. B., Maddock, W. O., Tokuyama, I., Paulsen, C. A. \& Nelson, W. A. (1956) Clinical studies of testicular hormone production. Recent Prog. Horm. Res. 12, 377.

Levin, L. (1945) The isolation of $\alpha$-estradiol from the urine of stallions. J. biol. Chem. 158, 725.

LEvin, L. (1949) The occurrence of $\alpha$-estradiol in the urine of stallions; its identification and isolation. 7. biol. Chem. 178, 229.

LoEwe, S. (1925) Nachweis brunsterzeugender Stoffe im weiblichen Blute. Klin. Wschr. 4, 1407.

LOEWE, S., Voss, H. E., LuNGe, F. \& WöHNER, A. (1928) Sexualhormonbefunde in männlichen Harn. Klin. Wschr. 7, 1376.

Lunaas, T. \& Velle, W. (1965) The effect of gonadotropins and synthetic gestagens on testicular steroid secretion in swine. Fifth Acta endocrinologica Congress, Acta endocr., Copenh. Suppl. 100, 41.

MAdDock, W. O. \& Nelson, W. O. (1952) The effects of chorionic gonadotropin in adult men: increased estrogen and 17-keto-steroid excretion, gynecomastia, Leydig Cell stimulation and seminiferous tubule damage. 7. clin. Endocr. Metab. 12, 985.

MARKer, R. E. (1939a) Ketonic steroids from cow's pregnancy urine and bull's urine. 7 . Am. chem. Soc. 61, 944.

Marker, R. E. (1939b) The steroidal content of steer's urine. F. Am. chem. Soc. 61, 1287.

Nyman, M. A., Geiger, J. \& Goldzieher, J. W. (1959) Biosynthesis of estrogen by the perfused stallion testis. F. biol. Chem. 234, 16.

Paschkis, K. E. \& Rakoff, A. E. (1950) Physiology of estrogenic hormones. Recent Prog. Horm. Res. 5, 115.

Pigoń, H., LunaAs, T. \& Velle, W. (1961) Urinary oestrogens in the stallion. Qualitative and quantitative investigations. Acta endocr., Copenh. 36, 131.

RAEsIDE, J. I. (1965) Urinary excretion of dehydroepiandrosterone and oestrogens by the boar. Acta endocr., Copenh. 50, 611.

Stegel, E. T., Dorfman, R. I., Brodey, R. S. \& Friedman, M. H. F. (1962) Conversion of 6,7-H33 estradiol into estrone and estradiol-17 $\alpha$ in the mature male dog. Proc. Soc. exp. Biol. Med. 111, 533.

VeLLE, W. (1957) Urinary oestrogen excretion by the bull. Nature, Lond. 180, 856.

VeLLE, W. (1958a) Isolation of oestrone and oestradiol-17 $\beta$ from the urine of adult boars. Acta endocr., Copenh. 28, 255.

VelLe, W. (1958b) Further studies on urinary oestrogen excretion by the boar. Acta endocr., Copenh. 29, 395.

VELLE, W. (1958c) Undersekelser over naturlig forekommende ostrogener hos dravtyggere og gris (Investigations on naturally occurring oestrogens in ruminants and the pig). Thesis, Norges Veterinærhøgskole, Oslo.

VelLe, W. (1958d) Studies on oestrogens in cattle. Urinary oestrogen excretion by the newborn calf. Acta endocr., Copenh. 29, 381.

ZoNDEK, B. (1933) Neue Untersuchungen über das weibliche Sexualhormon (Follikelhormon). Ark. Kemi Miner. Geol. 11, B, No. 24, 1.

Zondek, B. (1934a) Mass excretion of oestrogenic hormone in the urine of the stallion. Nature, Lond. 133, 209.

ZoNDEK, B. (1934b) Oestrogenic hormone in the urine of the stallion. Nature, Lond. 133, 494. 